\title{
NOTES ON AUSTRALIAN COLEOPTERA, WITH DESCRIPTIONS OF NEW SPECIES.
}

Ry the Rev. T. Blackburn, B.A., Corr. Mem. Linn. Soc. N.S.W.

\section{PART VI.}

\section{CALLOODES.}

This genus appears to be of very doubtful validity. Its author mentions no definite character. M. Lacordaire sinks it as synonymous with Anoplognathus. But in 1874 (Trans. Ent. Soc. p. 537) Mr. C. O. Waterhouse states that it is a good genus and mentions as salient distinctive characters that the anterior tibiæ are simply produced at the apex on the outer side,- -having no teeth on the outer edge, - and that the apex of each elytron is slightly produced into a point. I do not believe the latter character is a satisfactory one, for there are species of Anoplognathus (e.g. Boisduvali, Dup., and nebulosus, Macl.) having the elytra quite as decidedly produced apically as those of any Calloodes I have seen,- - and I think I know all the species that have been attributed to the genus; the former character appears to me equally unsatisfactory for in some species of Calloodes at least it pertains to only one sex, and in others to neither. In C. Mastersi, Macl., (which most decidedly has entirely the facies and style of coloration of (alloodes) the front tibiæ are externally dentate in both sexes, while in $C$. prasinus, Macl, they are dentate in one sex (apparently the 0 !) only. C. Atkinsoni, Waterh., I am not absolutely sure that I know; the type I should judge to be a male,-if so a female Calloodes in my collection probably appertains to the species (though it differs from the description in having the elytra slightly dilated in the middle of the lateral margin as in some Anoplognathi (ㅇ) and also a little differently punctured as well as the usual sexual characters); its front tibiæ have a single very feeble and obtuse external tooth besides the apical prolongation. 
I am sorry that I can suggest no structural characters for the genus more reliable than those I have criticised, but after a protracted examination of a fairly numerous series of Anoplognathi and Calloodes I can find not one structural character nor any combination of structural characters that seem confined to and invariable in either genus. Nevertheless the distinction of the genera seems very desirable, for the species called Calloodes certainly differ from all described Anoplognathi in being genuinely metallic insects of pure brilliant colours (instead of being of some shade of red or testaceous with more or less metallic gloss or shimmer), of a wide Dytiscus-like form somewhat (though not very greatly) different from that of most if not all Anoplognathi.

\section{Calloodes frenchi, sp.nov.}

Argenteo-viridis; nitidissimus ; supra vix perspicue (capite excepto) punctulatus; elytris vix striatis; prothorace medio postice haud emarginato; labro, mento, antennis, palpis, pedibusque testaceis; corpore subtus (metasterni segmentorumque ventralium lateribus exceptis) vix perspicue punctulato, parce albido-piloso; mesosterno fortiter producto; pygidio sparsim obsolete punctulato, apice leviter barbato.

[Long. 7-8, lat. $3 \frac{3}{5}-4 \frac{2}{5}$ lines.

Maris clypeo antice sat anguste producto sparsim punctulato, supra obsolete bi-tuberculato; coxis anticis externe ad apicem bidentatis; unguiculis simplicibus.

Feminæ clypeo antice rotundato crebre punctulato; coxis anticis externe tridentatis; unguiculis externis anticis bifidis.

The clypeus in the male narrows forward for more than half its length and then dilates very slightly to its apex which is much narrower than its base, the front margin being gently rounded (in C. Mastersi the clypeus of the male is almost parallel-sided in its hinder two-thirds and then dilates to its apex which is quite as wide as its base).

The species closely resembles $C$. Mastersi, Macl., in colour, but the beautiful silvery gloss that overspreads its green colour is even 
more conspicuous. It differs completely from $C$. Mastersi in having the mesosternal process long and prominent, and also is very much less distinctly punctulate than that species (except on the clypeus of the female); the clypeus of the male differs as mentioned above; the lateral edging of the prothorax is continued from the hind angles only a very short distance along the base, and the base is less (in the male before me not at all, in the female scarcely) emarginate in the middle; in both sexes of $C$. Mastersi it is evidently though slightly emarginate; the elytra of C. Frenchi are not striated but bear some longitudinal scratch-like lines,more conspicuous in the female than in the male,- the puncturation in the former sex being not quite so obsolete as in the latter.

North Queensland; presented to me by C. French, Esq., Colonial Entomologist of Victoria.

\section{ANeurystypus Richardsæ, sp.nov.}

Castaneus ; subtus dense longe fulvo-hirsutus ; capite sat crebre, prothorace et scutello sparsim subtiliter, pygidio (apice sublævi excepto) sat crebre subrugulose, elytris subseriatim sat fortiter, punctulatis.

[Long. 6-7, lat. $3 \frac{1}{2}-4$ lines.

Mas. Antennarum flagello articulis ceteris conjunctis vix longiori ; prothorace antice impresso, margine anteriori acute elevato.

Fem. Latet.

Closely allied to A. calvus, Blackb., from which it differs as follows: the club of the antennæ in the male is very much shorter (in A. calvus it is about twice as long as all the other joints together); the prothorax and scutellum are much less strongly punctured and the former is differently shaped, its greatest width being scarcely more than half again its length down the middle, the sides being somewhat parallel in the hinder half whence they converge arcuately to the front, and the base being much less strongly bisinuate (so that its middle part appears to be less lobed hindward) and being scarcely or not margined (in calvus the margin is well defined). The bunches or fringes of hairs over the scutellum and pygidium are much less dense (possibly this might 
not be the case in a fresh example), the puncturation of the elytra is not so distinctly seriate, and the puncturation of the basal portion of the pygidium is very much closer and more rugulose, though scarcely so strong.

The comparative shortness of the flagellum of the antennæ might appear suggestive of merely sexual difference between this and the older species, but I think there is no doubt that all I have seen of either species are males, since not only are the prothoracic excavation and armature similar (though varying a little in individual development) but they all have the anterior ventral segments very short and the hind tarsi moderately long, whereas in Corynophyllus, Cavonus and other allied genera the former are much longer, and the latter much shorter in the female than in the male. It is hardly likely either that all the examples before me from one locality should be males and all from another locality females. The external teeth of the front tibiæ are strong and sharp as in $A$. calvus; in one example however they are more feebly developed, and this I take to be merely an individual peculiarity, though it may possibly be indicative of a third closelyallied species.

Taken in the Lake Eyre Basin by Mrs. Richards of Beltana, a lady who has long been a successful and interested collector of the Australian fauna in various parts of S. Australia, and whose work I am glad of the opportunity of commemorating by the association of her name with one of the S. Australian species she has collected.

N.B.-In characterising the genus Aneurystypus I stated that it differed from Corynophyllus in the mouth organs as well as in the shape of the flabellum. The mouth organs of A. Richardsce however are not quite like those of $A$. calvus; the mentum being slightly wider (but quite distinct from that of the Corynophylli I have dissected) while the maxillary palpi come nearer to Corynophyllus. I suspect that the mouth organs are given to vary specifically in insects that cannot be generically separated, and are not very reliable characters for generic distinction (at any rate in the Dynastida). The narrow flabellum of the antennæ however 
strongly distinguishes Aneurystypus from Corynophyllus, and is accompanied by an evident difference of general facies which I think justifies the validity of the separation. In A. Richardsce the 2 nd joint of the maxillary palpi is distinctly shorter and less pyriform than in A. calvus.

\section{Glycyphana subdepressa, sp.nov.}

Sat depressa; haud pilosa; purpureo-nigra, prothoracis disco obscuriori, capite antice rufescenti; prothoracis disco, elytrorum fasciis 2 interruptis maculisque nonnullis, pygidio ad latera, et corpore subtus, maculatim albidis; capite fortiter punctulato; prothorace quam longiori fere dimidio latiori, sparsim leviter sat crasse squamoso-punctulato, angulis posticis nullis; elytris singulis 2 -costatis (costis postice connexis), in parte dimidia antero-interna vix perspicue punctulatis, latera apicemque versus punctulatis, strigis transversis prope margines laterales pro puncturis substitutis; pygidio transversim sat crebre rugato; sternis arcuatim, segmentis ventralibus transversim subseriatim, crasse punctulatis ; tibiis anticis 3 -dentatis, dentibus 2 apicalibus altero sat longioribus.

[Long. $7 \frac{3}{4}$, lat. 4 lines.

The hind angles"of the prothorax are completely rounded off and the base is moderately and arcuately emarginate in the middle, the front margin is somewhat produced in the middle, and is less than half as wide as the widest part of the segment, the front angles being very obtuse but not quite rounded off. The markings on the elytra are probably variable; in the example before me there are on each elytron (a) a few small spots (mostly forming longitudinal lines) in the front half, (b) two transverse larger spots forming an interrupted fascia (one touching the lateral margin just behind the middle and thence running obliquely towards the hind end of the scutellum, but extending less than half the distance thereto, the other placed quite transversely on a level with the external end of its oblique fellow and reaching from the outside of the sutural carina to the inner edge of the outer elytral costa), (c) a narrow line somewhat within the apical border but not reaching 
the suture. The outer costa on the elytra curves from the shoulder (towards the suture) to a callus near the apex, about half way between the suture and lateral margin; the inner costa is nearly parallel to the outer one, is nearer to it than to the suture, and joins it on the subapical callus. Both costæ are wide and rounded and (except near their apex) only feebly defined; the front half of the space between them is occupied by a double line of elongate scratch-like punctures which become continuous or stria-like in the hinder half, a sinailar stria-like scratch bordering the inner edge of the inner costa in its hinder half, and another (interrupted in the middle) running close outside the sutural costa. Outside the outer costa genuine puncturation begins, which, however, in the hinder half of the elytron, and at its apex, changes near the margin into a system of transverse strong scratches. The upper tooth on the external margin of the front tibiæ is similar to the lower ones but decidedly smaller than them. The mesosternal process projects forward in a somewhat tubercle-like manner from the level of the intermediate coxæ.

This species belongs to a section of Glycyphana not previously recorded as Australian, distinguished from the section in which C. brunnipes, Kirby, falls by the absence of scale-like hairs on the upper surface, the teeth on the anterior tibiæ, and many other characters. It is structurally near to some Javanese species, but I do not know of any that resembles it specifically,

N. Queensland; presented to me by C. French, Esq.

Neocuris viridiaurea, Macl.

In my own collection there is an example, and the South Australian Museum contains another, which would not appear capable of being separated from this species, as described by its author. The species belongs to the section of the genus (as divided by M. Fairemaire), having the head devoid of a longitudinal excavation: in my example the head is not quite absolutely without indications of concavity down the middle, but in that of the South Australian Museum, and also that 
described by Sir William Macleay, the impression appears to be in no way even indicated. In that section the present insect is the only one hitherto described of uniform colour; it bears much general resemblance to the species of the first section (especially $N$. viridimicans, Fairm.), but differs from most or all of them in its head being much less produced forward, as well as devoid of a longitudinal excavation. It is doubtful whether these insects were taken in the N. Territory or in S Australia proper, the record of particulars of capture being absent in the case of each of them.

Neospades (Cormbus) chrysopygius, Germ.

Mr. Duboulay has recently sent me this species from Victoria, and I have seen a considerable number of examples taken in S. Australia. I find that the colouring of the elytra varies much. The example described by me (Trans. Roy. Soc. S.A. X. p. 251) was a brightly coloured one. The green colouring of the elytra, however, is liable to be wanting in varying degrees until in some examples the elytra are of an almost uniform dull coppery colour, with some patches of grey scales. There does not seem to be much difference in description between this insect and C. Westwoodi, L. and G. If they are identical, the latter name will take precedence.

\section{Pteroheleus geminatus, sp.nov.}

Oblongus; vix nitidus; subconvexus; niger, labro testaceo, antennis palpis tarsis et marginibus reflexis subferrugineis; prothorace vix canaliculato, antice fortiter arcuatim emarginato, subtiliter sparsius ${ }^{\frac{\pi}{p}}$ punctulato, ad basin utrinque foveolato, marginibus concavis subæqualiter sat latis; elytris subtiliter (postice vix evidenter) seriatim punctulatis, seriebus in disco geminatis, marginibus concavis apicem versus gradatim angustatis.

[Long. $8 \frac{1}{4}$, lat. $4 \frac{4}{5}$ lines.

The lines of punctures (which are very fine, even finer than those of $P$. nitidissimus, Pasc.) on the elytra are arranged as 
follows ; next the suture (which is not elevated) is a rather wide lævigate space; then come 4 lines of punctures close together and a little confused inter se, then a lævigate interval, then 4 lines similar to those already described, then a lævigate interval, then 2 lines of punctures followed by a lævigate interval, beyond which are 2 more lines of punctures and then another lævigate interval, between which and the margin the puncturation is a little stronger and much confused. In the basal $\frac{1}{8}$ part of the elytra the punctures are spare and quite confused, and in the apical $\frac{1}{5}$ they become so faint as to be scarcely visible under a strong lens. The elytra though sub-opaque have a slight silky gloss.

This species seems to resemble $P$. agonus, Pasc., which however is very insufficiently described, no information being given (e.g.) as to the form of the prothoracic and elytral margins. That insect would seem to be much smaller (long. 5-6 lines) than the present one, and the lines of punctures on the elytra to be evenly spaced; nor is there any mention of the lines of punctures on the elytra being confused at the base and obsolete towards the apex, nor of the conspicuous foveiform impression at the base of the prothorax on either side intermediate between the middle line and the margin ; the prothorax moreover is said to be "nearly impunctate," whereas in the present species that segment under an ordinary lens is very distinctly, though finely, punctulate. It would probably be impossible to identify $P$. agonus positively except by examina tion of the type.

Northern Interior of S. Australia; taken by Mrs. Richards, probably in the Lake Eyre Basin.

\section{Disterna.}

This genus appears to me far too near Zygocera to be placed, as Lacordaire places it, in a different "Groupe" of the Lamiidae; I am even a little sceptical as to its right to be separated from Zygocera at all : in Masters' "Catalogue descr. Col. of Australia" its species appear under Zygocera. Lacordaire distinguishes the "groupe" Disternides from the Zygocerides by the absence of an oblique sinus on the intermediate tibiæ and the truncation of the 
prosternum in front. Now if Zygocera pruinosa, Boisd., be compared with various other species that have been described as congeneric with it, it will be found that in few if any of the latter is the intermediate tibia absolutely without any trace of the oblique sinus [it is scarcely less marked in (Disterna) plumifera, Pasc., than in Zygocera canosa, Er.], and also that the form of the prosternum varies somewhat $[e . g$. being very much different in (Disterna) plumifera, and very little different in (D.) lugubris, Pasc., from the same in Zygocera pruinosa and canosa]. On the other hand the facies and style of markings differ so little except in degree, and there is so striking a character common to all the Australian species hitherto attributed to either genus, viz., the presence in one sex at least of a large apical or subapical depression or fovea on the more or less glabrous last ventral segment, that I do not see how they can be regarded as at most more distinct than two closely allied genera. I cannot see how they are to be differentiated more strongly than as follows: ZYGOCERA, surface nitid with scanty pubescence forming spots or fasciæ, external sinus of intermediate tibiæ fairly well developed; Disterna, - pubescence much more extended on the surface rendering it in general opaque; external sinus of intermediate tibiæ almost or quite obsolete.

The degree of contiguity of the base of the antennæ varies but does not seem to be generic $[e . g . Z$. canosa and D. lugubris appear intermediate in this respectbetween $Z$. pruinosa and D. plumifera].

\section{Glenea.}

I have recently received from Mr. French, the Victorian Colonial Entomologist, an example of this genus (hitherto not recorded, as Australian), which that gentleman tells me was taken in North Queensland. It does not appear to me to differ specifically from picta, Fab., which has a wide distribution in Polynesia.

\section{Calomela eyrei, sp.nov.}

Oblonga; fulvo-testacea, capite elytris et prothoracis sternique lateribus plus minus viridi-tinctis, antennis apicem versus piceis; 
capite fortiter sat crebre, prothorace (disco sparsim subtiliter, latera versus crassissime) elytris subtiliter confuse (his suturam versus subseriatim) punctulatis.

[Long. 2-2 $\frac{1}{4}$, lat. 1 line.

The prothorax is twice as wide as it is long down the middle, its front margin being very little wider than the base, the sides very gently arched and the surface even, transversely rather strongly convex; the front margin is widely and feebly emarginate, and is widely and strongly produced in the middle; all the angles are sharp. In a brightly coloured example the whole of the head scutellum and elytra, together with the margins of the prothorax, appear in a certain light of a bright clear green colour, while, from a different point of view, the colour appears more purplish ; in more feebly coloured specimens the same parts are of a fulvous hue suffused with a metallic green gloss. In all the examples I have seen the elytra are quite unicolorous.

Compared with C. Curtisi, Kirby, this species (apart from differences of colour and size) has the elytra and the disc of the prothorax very much more feebly punctulate, the sides of the prothorax much less strongly and more evenly arched, and the front margin of the same strongly and almost evenly bisinuate, instead of being somewhat evenly and very deeply emarginate.

Interior of S. Australia, Lake Eyre Basin, or thereabouts; taken by Mrs. Richards. 


\section{$2 \mathrm{BHL}$ Biodiversity Heritage Library}

Blackburn, Thomas. 1890. "Notes on Australian Coleoptera, with descriptions of new species. Part VI." Proceedings of the Linnean Society of New South Wales 5, 147-156. https://doi.org/10.5962/bhl.part.18628.

View This Item Online: https://www.biodiversitylibrary.org/item/22899

DOI: https://doi.org/10.5962/bhl.part.18628

Permalink: https://www.biodiversitylibrary.org/partpdf/18628

\section{Holding Institution}

MBLWHOI Library

\section{Sponsored by}

MBLWHOI Library

\section{Copyright \& Reuse}

Copyright Status: NOT_IN_COPYRIGHT

This document was created from content at the Biodiversity Heritage Library, the world's largest open access digital library for biodiversity literature and archives. Visit BHL at https://www.biodiversitylibrary.org. 